\title{
Managing Diversity At Higher Education And Training Institutions: A Daunting Task
}

Mutendwahothe Walter Lumadi, North West University, Mafikeng Campus, South Africa

\begin{abstract}
Higher Education and Training Institutions (hereafter referred to as HETIs) are changing rapidly world-wide. Traditional academic cultures and relationships are being challenged, bringing new social dynamics to higher education systems and increasing diversity and differentiation within and between institutions. Against the backdrop of these changes, this article will attempt to shed light on the significance of diversity management at HETIs in the democratic country of South Africa. Although the scope of the study is South African driven, its recommendations may be relevant to all institutions around the globe.
\end{abstract}

\section{BACKGROUND AND INTRODUCTION}

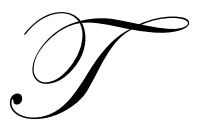

he change in the demographic structure of the South African workforce mirrors the diversity of the South African population as a whole. This diverse customer base and the increased importance of globalization for South African industry will challenge institutions to appeal to a diversified marketplace. The challenge of recruiting, selecting and managing a diverse workforce is necessary for organizational survival (Grobler, Warnich, Carrell, Elbert \& Hatfield, 2002 : 45).

Diverse teams in HETIs are more proactive, innovative and able to solve with ease whatever problems arise. The fuel of creativity depends largely on diversity in institutions. Different groups have different needs, and they want their needs recognized and met. Acknowledgement of different needs yields greater employee satisfaction, employer loyalty and, in turn, lowers staff turnover and leads to greater productivity.

Capozza and Brown (2000:18) show that a positive response to demographic changes and equity promotion in the workforce enhances institutional performances and reputation. Actions that promote diversity for both academic and administrative staff are those that lead to a work environment that maximizes the potential of all employees whilst also acknowledging their unique contributions and differences.

Making distinctions between employees in a work setting subsequently results in the exclusion of minorities from group membership and important decision-making processes and gives them less access to support, which, in turn, jeopardizes career advancement. The perception of unfair treatment eventually creates an overall negative work environment for employees. In South African organizations in particular, the concept diversity has 3 major working definitions which are;

- $\quad$ The politically correct term for employment equity or affirmative action.

- $\quad$ The recruitment and selection of ethnic groups and women and

- $\quad$ the management of individuals sharing a broad range of common traits

(Grobler, et al, 2002:46).

It is imperative to note that the basic concept of managing diversity accepts that the workforce consists of a diverse population of people. The diversity consists of people of visible and non-visible differences which will include factors such as age, gender, religion, political background, race, language, disability and marital status (see figure 1.1 for dimensions of diversity). 


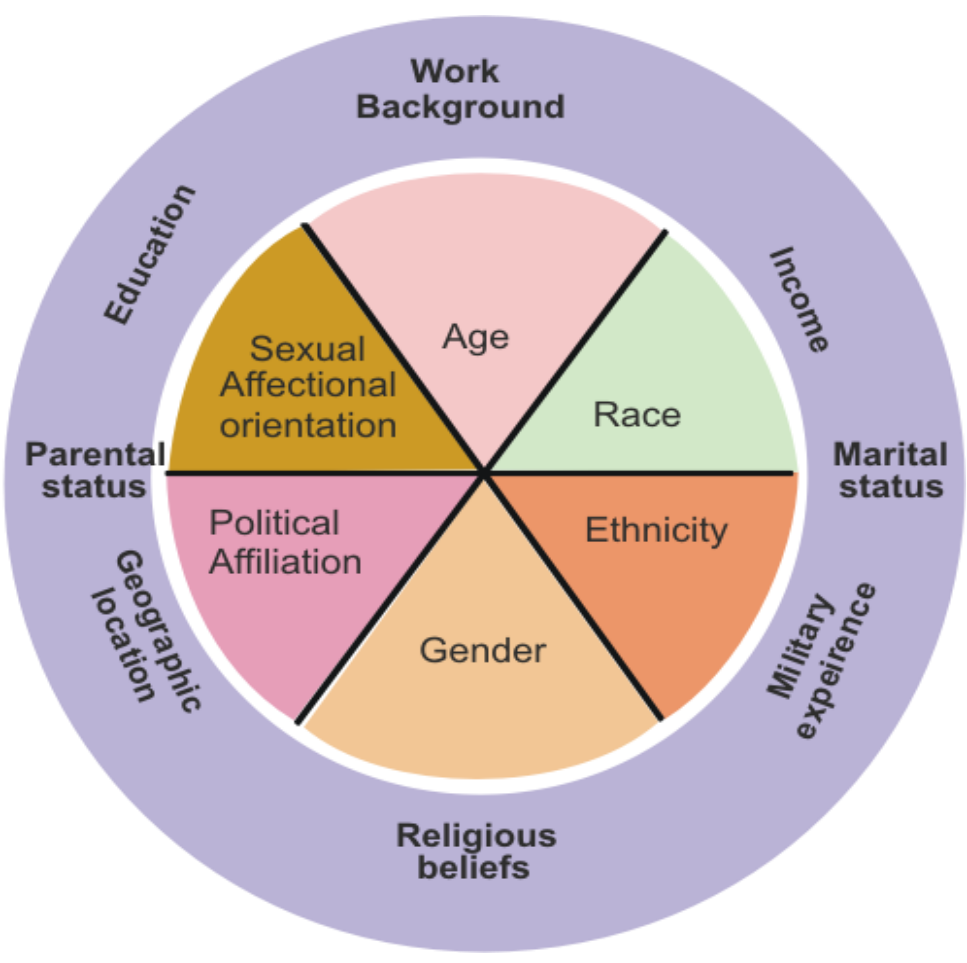

Figure 1.1: Dimensions of diversity

It is founded on the premise that harnessing these differences will create a productive environment in which everyone feels valued, where their talents are being fully utilised and in which institutional goals are met (Kandola $\&$ Fullerton, 2002).

\section{RESEARCH METHODOLOGY}

The information needed to compile this article was collected by reviewing relevant literature on diversity management. Although there are 23 South African universities, the HETIs surveyed for this project included a population of 8 institutions of higher learning. This population of 8 universities one from each of the 9 South African Provinces except Northern Cape (see table 2.1 for South African Provinces and HETIs) was purposefully sampled because it is easily accessible, diverse, provincially based, and may also be representative of a larger population which could be addressed in future research.

Table 2.1: South African Provinces and sampled HETIs

\begin{tabular}{|l|c|c|}
\hline \multicolumn{1}{|c|}{ Province } & University & Location \\
\hline Eastern Cape & Nelson Mandela Metropolitan & Port Elizabeth \\
\hline Free State & Free State & Johannesburg \\
\hline Gauteng & University of Johannesburg & Durban \\
\hline KwaZulu Natal & KwaZulu Natal & Polokwane \\
\hline Limpopo & Limpopo & Nelspruit \\
\hline Mpumalanga & Tshwane Technology & Kimberly (Provincial Head Office) \\
\hline Northern Cape & No university & Mafikeng, Potchefstroom \& Vaal Triangle \\
\hline North West & North West & Cape Town \\
\hline Western Cape & Cape Town & \\
\hline
\end{tabular}


It is imperative to note that one of the Provinces of South Africa, namely, Northern Cape, does not have a university. This left the researcher with a total of $8 / 23$ educational institutions. The point of departure in data collection was to surf each HETIs' website to determine if the homepage and available documents referenced the concept of "diversity."

Both interviews and questionnaires which are normally associated with qualitative research design were used as research instruments for collecting data. Relevant data on the institutional definition of diversity was sought along with evidence that the organizational structure supported diversity. It is anticipated that in subsequent research this information will supplement data collected from the HETIs. Each institution was surveyed to obtain diversity data. Based upon information obtained from the research respondents who were Vice-Chancellors, Registrars, Rectors, Deans of Faculties and Directors of various sections, it became evident that they are charged with the effective management of the institution.

A major focus was to collect data about whether diversity was referenced in the university's vision and mission. In all the surveyed HETI, the researcher also collected data about language, religion, Affirmative Action, recruitment strategies, committee structure, curriculum, diversity training and diversity policies. Different languages are spoken in each of the Provinces (see table 2.2 for the dominant languages spoken in each of the Provinces where these universities are situated).

Table 2.2: Percentage distribution of home language by province

\begin{tabular}{|l|c|c|c|c|c|c|c|c|c|c|}
\hline $\begin{array}{c}\text { Population } \\
\text { group }\end{array}$ & $\begin{array}{c}\text { Eastern } \\
\text { Cape }\end{array}$ & $\begin{array}{c}\text { Free } \\
\text { State }\end{array}$ & Gauteng & $\begin{array}{c}\text { KwaZulu- } \\
\text { Natal }\end{array}$ & Mpumalanga & $\begin{array}{c}\text { Northern } \\
\text { Cape }\end{array}$ & $\begin{array}{c}\text { Limpopo } \\
\text { Province }\end{array}$ & $\begin{array}{c}\text { North } \\
\text { West }\end{array}$ & $\begin{array}{c}\text { Western } \\
\text { Cape }\end{array}$ & $\begin{array}{c}\text { South } \\
\text { Africa }\end{array}$ \\
\hline Afrikaans & 9.6 & 14.5 & 16.7 & 1.6 & 8.3 & 69.3 & 2.2 & 7.5 & 59.2 & 14.4 \\
\hline English & 3.7 & 1.3 & 13.0 & 15.8 & 2.0 & 2.4 & 0.4 & 1.0 & 20.3 & 8.6 \\
\hline IsiNdebele & 0.0 & 0.2 & 1.6 & 0.0 & 12.5 & 0.0 & 1.5 & 1.3 & 0.1 & 1.5 \\
\hline IsiXhosa & 83.8 & 9.4 & 7.5 & 1.6 & 1.3 & 6.3 & 0.2 & 5.4 & 19.1 & 17.9 \\
\hline IsiZulu & 0.4 & 4.8 & 21.5 & 79.8 & 25.4 & 0.3 & 0.7 & 2.5 & 0.1 & 22.9 \\
\hline Sepedi & 0.0 & 0.2 & 9.5 & 0.0 & 10.5 & 0.0 & 52.7 & 4.0 & 0.0 & 9.2 \\
\hline Sesotho & 2.2 & 62.1 & 13.1 & 0.5 & 3.2 & 0.9 & 1.1 & 5.1 & 0.4 & 7.7 \\
\hline Siswati & 0.0 & 0.1 & 1.3 & 0.1 & 30.0 & 0.0 & 1.2 & 0.5 & 0.0 & 2.5 \\
\hline Setswana & 0.0 & 6.5 & 7.9 & 0.0 & 2.7 & 19.9 & 1.4 & 67.2 & 0.1 & 8.2 \\
\hline Tshivenda & 0.0 & 0.1 & 1.4 & 0.0 & 0.1 & 0.0 & 15.5 & 0.4 & 0.0 & 2.2 \\
\hline Xitsonga & 0.0 & 0.5 & 5.3 & 0.0 & 3.5 & 0.0 & 22.6 & 4.7 & 0.0 & 4.4 \\
\hline Other & 0.2 & 0.3 & 1.3 & 0.5 & 0.4 & 0.8 & 0.3 & 0.5 & 0.6 & 0.6 \\
\hline Total & 100.0 & 100.0 & 100.0 & 100.0 & 100.0 & 100.0 & 100.0 & 100.0 & 100.0 & 100.0 \\
\hline
\end{tabular}

\section{SOME OF THE RESEARCH FINDINGS}

The key questions HETIs normally pose regarding diversity management are;

- Does the curriculum accommodate diversity?

- To what extent is it accommodated?

- How does the curriculum empower students from diverse backgrounds?

- Do HETIs create an environment in which Faculty and students from diverse backgrounds feel welcomed in all the activities offered by the institution?

It is crucial to note that the outcomes of research are not just a list of categories of description obtained from respondents. A particular category of description is always developed in terms of its relation with other categories of description. After data had been collected, the interviews were transcribed and the transcripts were subjected to rigorous analysis.

This involved reading all the transcripts and drafting a set of categories of description drawn from these transcripts. Such categories and outcomes served as tools to capture and communicate the features of conceptions. 
Findings in this study were based on the research instruments and literature review. Based on the analysis of data, various themes were identified.

\subsection{Multilingualism And Language Ombuds-Function}

South African universities acknowledge the realities of a multilingual society and a multilingual university environment. Consequently, the language management approach of the institutions leave room for different strategies and models for the implementation of functional multilingualism with this overarching multilingual context. Nelson Mandela Metropolitan, Free State, Johannesburg and Tswane University of Technology use both English and Afrikaans whilst KwaZulu Natal, Limpopo and Cape Town use English.

The regional languages that are used at the campuses of the North West University for instance, are Afrikaans, at the Potchefstroom Campus, Setswana, at the Mafikeng Campus, Sesotho at the Vaal Triangle Campus and English as an international language at all the three Campuses. These languages are regarded as national assets, and measurable contributions are made towards the use of these languages as languages of higher education.

The language policy and the language plan are linked to the institutional plan of the institution, and revised accordingly at three to five year intervals. The revision thereof is based on a proper situational analysis and a clear external and internal alignment process. The Institutional Language Directorate at the university fulfils a language ombuds-function in as far as it acts as point of reference and reporting for language related queries.

Both students, academic and administrative staff who believe strongly that their linguistic and privileges are neglected, have a right to file complaints and to interview all interested parties with a view to providing a solution in line with the institutional language policy. Feedback has to be provided within a period of seven working days. To ensure access at the Potchefstroom Campus, where Afrikaans is a language for undergraduate tuition, a system of simultaneous interpretation has been in place since the merger. The following teaching programmes are delivered by means of simultaneous interpretation;

- B. Engineering, B Pharmacy, B Cur(Nursing), LL.B, B. Com(HR and International Relations), and BA Honours in Theology at the Potchefstroom Campus

- $\quad$ BSc (IT) and BA in Language Practice at the Vaal Triangle Campus

\subsection{Religion}

More than $75 \%$ of the South African population belong to Christian churches. Other major religious groups are the Hindus, Muslims and Jews. All these major religions are found at South African HETIs. They are aware that freedom of worship is guaranteed by the Constitution and the official policy is one of non-interference and tolerance in religious practices.

At the University of Cape Town, the Religion and Social Change Unit which is located in the Department of Religious Studies in the Faculty of Social Science and Humanities plays a prominent role in teaching students, academic and administrative staff to accept and respect each other's religion. This unit which was established in 1994 coordinates the Institute for Comparative Religion in South Africa and the Research Institute for Christianity in South Africa. All institutions remedy the inequalities which are both structural and historically derived by understanding that there is no religion which is superior or inferior to the other. Instead, all religions regardless of their uniqueness are viewed on an equal footing.

A pro-diversity approach to teaching and learning is certainly the best way to manage diversity. This approach has to centre on a transformative curriculum and diversified pedagogical approach which can equip educators to meet the challenges of a teaching and learning environment. The HETIs curriculum conscientises students to accept, tolerate and respect each other's religions regardless of its diverse background. 


\subsection{Affirmative Action (AA)}

Political, demographic and economic factors in South Africa require employers to use more flexible and innovative recruitment strategies. The largest potential source of workers in South Africa is non-working women caring for their families at home. The so-called designated groups identified by Government in the Employment Equity Acct, no.55 of 1998 as Blacks, Asians, Coloureds, women and persons with disability will play a vital role in occupying senior positions at HETIs. It is imperative to note that concepts such as race, gender and disability as biological conditions should not be confused with ramifications. Executive management is committed to transforming positive rhetoric on equality and diversity into practical changes within HETIs in South Africa resulting in;

- $\quad$ A more open and inclusive culture that actively promotes equality and diversity across all strands including sexual orientation, disability, race, age and gender.

- The appointment of disabled people and women especially blacks, in leadership positions at all levels who reflect the composition of the staff (at all committees), student population (Student Representative Council) and wider society they serve

- $\quad$ Encourage use of mentoring and succession planning to enable the previously disadvantaged people to assume leadership responsibilities

(See table 2.3 for disabled population in South African HETIs and figure 1.2 for unemployment rates in the country).

Table 2.3: Disabled population by type, gender and population group

\begin{tabular}{|c|c|c|c|c|c|c|}
\hline Disability & African/black & Coloured & Indian/Asian & White & $\begin{array}{c}\text { Unspecified/ } \\
\text { Other }\end{array}$ & Total \\
\hline $\begin{array}{l}\text { Sight } \\
\text { Male } \\
\text { Female } \\
\text { Total } \\
\end{array}$ & $\begin{array}{c}397449 \\
605396 \\
1002845 \\
\end{array}$ & $\begin{array}{l}15308 \\
19254 \\
34562 \\
\end{array}$ & $\begin{array}{c}7239 \\
8384 \\
15623 \\
\end{array}$ & $\begin{array}{l}16247 \\
16620 \\
32867 \\
\end{array}$ & $\begin{array}{l}2142 \\
2884 \\
5026 \\
\end{array}$ & $\begin{array}{r}438385 \\
652538 \\
1090923 \\
\end{array}$ \\
\hline $\begin{array}{l}\text { Hearing } \\
\text { Male } \\
\text { Female } \\
\text { Total } \\
\end{array}$ & $\begin{array}{l}154538 \\
177708 \\
332246 \\
\end{array}$ & $\begin{array}{c}7716 \\
7841 \\
15557 \\
\end{array}$ & $\begin{array}{l}2601 \\
2348 \\
4949 \\
\end{array}$ & $\begin{array}{l}14906 \\
13380 \\
28286 \\
\end{array}$ & $\begin{array}{r}1091 \\
1280 \\
2371 \\
\end{array}$ & $\begin{array}{l}180852 \\
202557 \\
383409\end{array}$ \\
\hline $\begin{array}{l}\text { Physical } \\
\text { Male } \\
\text { Female } \\
\text { Total }\end{array}$ & $\begin{array}{l}223680 \\
363337 \\
587017 \\
\end{array}$ & $\begin{array}{l}19032 \\
13674 \\
32706 \\
\end{array}$ & $\begin{array}{l}5653 \\
4111 \\
9764 \\
\end{array}$ & $\begin{array}{l}13821 \\
11291 \\
25112 \\
\end{array}$ & $\begin{array}{ll}1638 \\
1537 \\
3175 \\
\end{array}$ & $\begin{array}{l}263824 \\
393950 \\
657774 \\
\end{array}$ \\
\hline $\begin{array}{l}\text { Mental } \\
\text { Male } \\
\text { Female } \\
\text { Total } \\
\end{array}$ & $\begin{array}{c}95550 \\
66056 \\
161606\end{array}$ & $\begin{array}{c}8471 \\
5877 \\
14348 \\
\end{array}$ & $\begin{array}{l}2391 \\
1659 \\
4050 \\
\end{array}$ & $\begin{array}{r}6162 \\
4960 \\
11122 \\
\end{array}$ & $\begin{array}{c}842 \\
587 \\
1429 \\
\end{array}$ & $\begin{array}{c}113416 \\
79139 \\
192555\end{array}$ \\
\hline $\begin{array}{l}\text { More than } \\
\text { one } \\
\text { Male } \\
\text { Female } \\
\text { Total }\end{array}$ & $\begin{array}{c}53031 \\
79739 \\
132770\end{array}$ & $\begin{array}{l}2880 \\
3196 \\
6076\end{array}$ & $\begin{array}{l}1498 \\
1445 \\
2943\end{array}$ & $\begin{array}{c}5873 \\
5653 \\
11526\end{array}$ & $\begin{array}{l}413 \\
509 \\
922\end{array}$ & $\begin{array}{c}63695 \\
90542 \\
154237\end{array}$ \\
\hline $\begin{array}{l}\text { Unspecified } \\
\text { Male } \\
\text { Female } \\
\text { Total }\end{array}$ & $\begin{array}{c}99081 \\
109250 \\
208331 \\
\end{array}$ & $\begin{array}{l}12273 \\
12445 \\
24718 \\
\end{array}$ & $\begin{array}{l}2680 \\
3821 \\
6501 \\
\end{array}$ & $\begin{array}{l}18277 \\
18259 \\
36536 \\
\end{array}$ & $\begin{array}{l}1770 \\
1864 \\
3634 \\
\end{array}$ & $\begin{array}{l}134081 \\
145639 \\
279720\end{array}$ \\
\hline $\begin{array}{l}\text { Total } \\
\text { Male } \\
\text { Female } \\
\text { Total }\end{array}$ & $\begin{array}{l}1023329 \\
1401486 \\
2324813 \\
\end{array}$ & $\begin{array}{c}65680 \\
62287 \\
127967\end{array}$ & $\begin{array}{l}22062 \\
21768 \\
42830 \\
\end{array}$ & $\begin{array}{c}75286 \\
70163 \\
145548\end{array}$ & $\begin{array}{c}7896 \\
8661 \\
16555 \\
\end{array}$ & $\begin{array}{l}1194253 \\
1564365 \\
2657713 \\
\end{array}$ \\
\hline
\end{tabular}




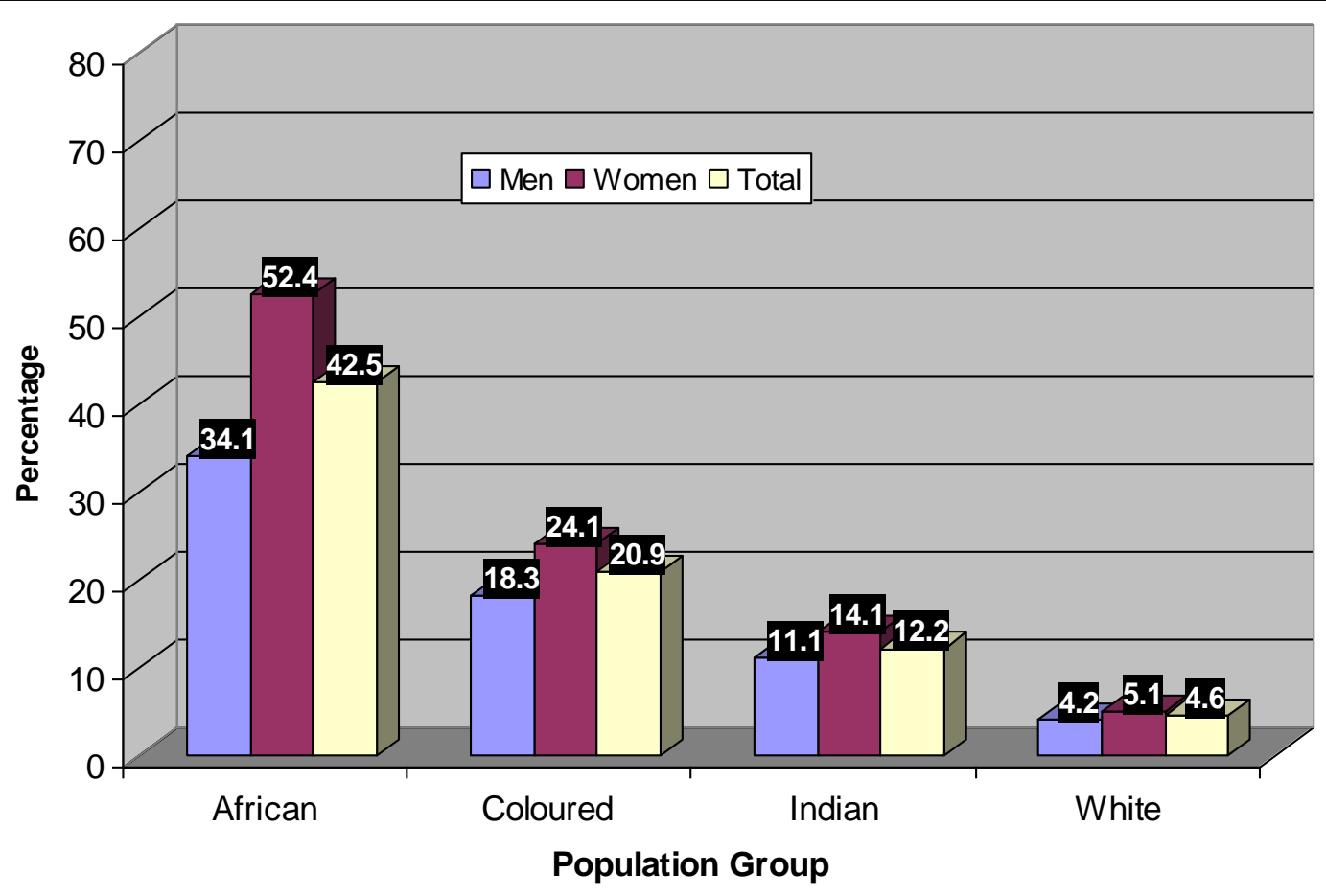

Figure 1.2: Unemployment rates

\subsection{Recruitment}

Sisson (2000:10) describes recruitment as those activities in Human Resources which are undertaken in order to attract sufficient job candidates who have the necessary potential, competencies and trades to fill job needs and to assist the organisation in achieving its goals. For HETIs to recruit the best applicants for a job is a mammoth task. Although South African institutions attempt to increase the workforce diversity, they find it taxing to lure culturally diverse candidates. It became evident when data was collected that they have established data banks containing profiles on different ethnic groups for top positions.

HETIs advertise on newspapers such as Sunday Times and City Press and even online. For top managerial positions, employment agencies and technology also plays a prominent role even in recruiting for institutions. Some universities bought time on Television channels for advertising posts with the aim of attracting the most qualified academics such as professors who are Chartered Accountants, Engineers, Lawyers and Medical Doctors. Some of the staff members who are currently university employees were interviewed telephonically and through video conferencing.

\section{RECOMMENDATIONS}

\subsection{Policy Review}

- Let there be an assessment of institutional policy on annual basis. Biases that create potential challenges for diverse academic and administrative staff should be avoided at all costs. 
- Diversity initiatives such as recruitment and selection, mentoring, staff retention, performance appraisal and succession planning should be considered to ascertain if the workplace is structured to exclude certain employee groups.

- $\quad$ Adverts for jobs should be widened to attract applicants from different backgrounds.

\subsection{Diversity scoreboard}

- The scoreboard is an important instrument for managing diversity. It should include financial and nonfinancial recognition of diversity initiatives as well as feedback.

- Diversity should be included in the vision and mission of the institution. Key deliverables that leverage the role of the diversity in the institution's overall strategy and the efficiency of the diversity deliverables should be included.

\subsection{Chain Reaction}

- $\quad$ A chain reaction should be created by influencing other HETI in the supply chain, to address diversity issues too.

- $\quad$ By networking, one is simply exposed to different approaches to diversity management. Where challenges are experienced, best practices can be recommended. This will enable the institution to have a competitive and innovative workforce.

- $\quad$ The institution's profile should be raised by making linkages with HETI of good reputation such as Oxford, Cambridge in the United Kingdom, Harvard, Stanford, Yale in the United States of America and other institutions of good standing world-wide. Where possible, the institution should be involved in community festivals.

- $\quad$ HETIs should extend the diversity standards for selection to programmes and aim to improve the balance of participation amongst the different equality groups.

\subsection{Communication}

- $\quad$ Visibility, communication and accountability are key to achieving a competitive diverse workforce.

- $\quad$ Let there be effective communication in the entire institution regarding diversity as a business strategy. It should flow from the Vice-Chancellor's office to senior management such as Deputy Vice-Chancellor, Registrar, Rectors, Vice-Rectors, Deans of Faculties and Directors of units. Faculty boards, Senate and Council should ensure that diversity initiatives are not frustrated.

- $\quad$ Statements and visual images that reinforce the institution's commitment to diversity should be displayed. This should be easily accessed by staff members from intranet, notice-boards and accessible in an format for the visually- impaired group.

\subsection{Group Needs}

- $\quad$ The needs of diverse groups should be met. The institution should announce new measures such as menus in staff and student cafeterias that reflect dietary needs and places set aside for religious purpose. Vegetarians should also be accommodated in these restaurants. Cultural days respecting different cultures should be marked on the calendar and be celebrated.

\subsection{Employees With Disabilities}

- $\quad$ This group is a source of underrepresented talent in the workplace. Top management should hire qualified individuals with disabilities on their staff. Working in a diverse institution requires diversity competencies for all employees. 


\subsection{Exit Interviews}

- $\quad$ The institution should collect and analyse data for diversity initiatives. Research instruments such as questionnaires and structured interviews should be used to determine how diversity management is viewed by the university community. Let there be confidential employee surveys and exit interviews for those who resign. Sometimes these employees might be forced to throw in the towel due to a diversity policy that is neglected.

\section{SUMMARY AND CONCLUDING REMARKS}

From the foregoing discussion, it became evident that diversity is a key element in any successful workplace. For any HETIs to be successful, its diverse workforce must be united. Managing demographic diversity in the workplace is a daunting task necessitating perseverance, commitment and dedication. The justification for promoting diversity in a multicultural work environment is based on the claim that policies create better decision making processes and enhance creativity and innovation. Effective training on how to work in a diverse environment helps HETIs prevent discrimination and promote inclusiveness. There is evidence that managing a diverse workforce well can contribute to increased staff retention and productivity.

Effective management thus enhances the institution's responsiveness to an increasingly diverse world of clients, improves relations with the surrounding community, increases the HETIs ability to cope with change and expands the creativity of the institution. Good management of a diverse workforce thus enhances the ability of the HETIs to manoeuvre in an increasingly complex and diverse environment. Social identity theory suggests that people identify more with members who are similar to their category than with dissimilar out-group members. Such distinctions and attachments affect their group and self-attribution, including stereotyping attribution.

Although Affirmative Action (AA), Equal Employment Opportunity (EEO), and diversity vary, they are intertwined. Each is directed toward achieving equal opportunity in the workplace. Diversity and AA each broaden the concept of EEO in different ways. Diversity, AA and EEO provide a strong foundation for the system's effort to create fair and inclusive workplaces. It is thus imperative to note that all factors should be viewed on an equal footing.

In conclusion, diversity management is the process of creating and maintaining a positive environment where the differences of all personnel are recognised, understood and valued, so that all can achieve their full potential. AA attempts to atone for past discrimination against certain groups of people. Because it tries to even the playing field for these groups, it does not apply to all people equally. In this study, it became evident that diversity management at HETIs is about the exploration of differences in a safe, positive and nurturing environment. From all the 8 surveyed institutions of Higher Learning, it was apparent that managing diversity is about understanding each other and moving beyond simple tolerance to embracing and celebrating the rich dimensions of diversity contained within each individual.

\section{AUTHOR INFORMATION}

Professor M. W. Lumadi is an experienced Curriculum Developer. He has worked at numerous Higher Education and Training institutions in South Africa, such as Westminster College of Education (as Rector), South African College for Teacher Education in Pretoria, University of Venda for Science and Technology, Kingdom International College (as dean), and, currently, North West University (NWU). Since 2003, he has served at various managerial committees in NWU and is currently director of the School of Postgraduate Studies. He is a member of Campus and Institutional Senate, Chairperson of Research, Commissioner of Oath, and Member of Council. Professor Lumadi is also an external examiner for Limpopo, Free State, Johannesburg, Tswane University of Technology, University of South Africa, Walter Sisulu, and Zululand. 


\section{REFERENCES}

1. Doherty, N. 1998. The role of outplacement in redundancy management, Personnel review, 27(4): 343-51

2. Finnemore, M. 2002. Introduction to Labour Relations in South Africa. Durban: Butterworths.

3. Giles, E. and Williams, R. 1991. Can the personnel department survive quality management? Personnel Management. April:28-33.

4. Grobler, P.A., Warnich, S, Carrell, M.R, Elbert, N.F. and Hatfield, R.D.2002.Human Resource Management in South Africa. $2^{\text {nd }}$ edition. Australia: Thomson.

5. Hendry, C. 1994. Human Resource Management, a strategic approach to employment. London: Butterworth.

6. Heriot, P. and Pemberton, C. 1995. New deals, the revolution in Management careers. London: Wiley.

7. Kennedy, T. 1990. HRM, rhetoric, reality and contradiction, International journal of Human Resource Management, 1(3):363-84.

8. Kennedy, C. 1996. The incredible shrinking company. Director. April: 62-68.

9. Legge, K 1995.Human Resource Management: Rhetorics and realities. Basingstoke: Macmillan.

10. Nel, P.S, Gerber P.D, Van Dyk P.S. Haasbroek G.D, Schultz H.B, Sono T. and Werner A. 2001. Human Resources Management. $5^{\text {th }}$ Edition, Oxford University.

11. Meyer, M, Malsaw, J \& Lancaster, K. 2001. ETD Practices in South Africa. Durban: Butterworth Publishers. Press. South Africa.

12. Sisson, K. 1990. Introducing the Human Resource Management journal, Human Resource Management journal 1 (1) 1-11.

13. Ulrich, D. 1997. Tomorrow's Human Resource Management. $1^{\text {st }}$ edition. New York: Wiley.

14. Wass, V. 1996. Who controls selection under voluntary redundancy?, British journal of Industrial Relations. 34(2): 249-265.

\section{KEY CONCEPTS}

\section{Affirmative Action: AA}

AA refers to a reverse discrimination policy that has as its object the amelioration of conditions of individuals who are socially or economically disadvantaged. It can also be viewed as a policy intended to promote access to employment aimed at a historically socio-politically non-dominant group particularly women. Motivation for AA is to redress the effects of past discrimination and to encourage public institutions such as universities to be more representative of the population.

\section{Diversity:}

The concept of diversity encompasses acceptance and respect. It also focuses on understanding that each individual is unique, and recognising our individual differences. These can be along the dimensions of race, ethnicity, gender, sexual orientation,, socio-economic status, age, physical abilities, religious beliefs, political beliefs, or other ideologies.

\section{HETIs:}

The acronym for Higher Education and Training Institutions. These are Institutions of Higher Learning such as Universities. It is at these institutions where one can register to study for a diploma, degree or do scientific research. 


\section{NOTES}

